\title{
PENGARUH PENGGUNAAN MEDIA POWERPOINT TERHADAP MINAT DAN HASIL BELAJAR IPA SISWA KELAS IV SD
}

\author{
Nira Elpira, Anik Ghufron \\ Dinas Pendidikan Kab. Pelalawan Riau, Universitas Negeri Yogyakarta \\ niraelpira80@gmail.com, anikgh@telkom.net
}

\begin{abstract}
Abstrak
Penelitian ini bertujuan untuk mengetahui pengaruh penggunaan media Powerpoint terhadap minat dan hasil belajar IPA siswa kelas IV SD Muhammadiyah Sagan. Jenis penelitian ini quasi eksperiment dengan desain One-Group pretest-posttest design. Populasi penelitian ini adalah semua siswa kelas IV SD Muhammadiyah Sagan pada semester pertama Tahun Ajaran 2013/2014. Variabel penelitian meliputi variabel bebas (penggunaan media Powerpoint) dan variabel terikat (minat dan hasil belajar). Sample penelitian adalah siswa kelas IVA SD Muhammadiyah Sagan Tahun Ajaran 2013-2014. Penelitian ini dilaksanakan pada semester I Tahun Ajaran 2013-2014. Pengumpulan data menggunakan tes dan non tes. Instrumen pengumpulan data adalah tes hasil belajar berbentuk pilihan ganda dan angket minat belajar. Data penelitian ini diambil dari data hasil tes dan non tes, dengan membandingkan rata-rata sebelum dan sesudah pembelajaran. Hasil penelitian ini menunjukkan bahwa penggunaan media Powerpoint IPA terbukti berpengaruh terhadap minat dan hasil belajar.
\end{abstract}

Kata kunci: media Powerpoint, minat belajar, hasil belajar

\section{THE EFFECT OF POWERPOINT MEDIA USE ON STUDENTS' LEARNING INTEREST AND OUTCOMES OF NATURAL SCIENCE LESSON OF THE FOURTH GRADE IN ELEMENTARY SCHOOL}

\author{
Nira Elpira, Anik Ghufron \\ Dinas Pendidikan Kab.Pelalawan, Universitas Negeri Yogyakarta \\ Niraelpira80@gmail.com, lppmuny@gmail.com
}

\begin{abstract}
This research aimed to investigate the effect of media Powerpoint use on the interest and outcome of learning natural science of the fourth grade students at elementry school. This research was quasi-experimental using one-group pretest-posttest design. The populations comprised the fourth grade students of elementry school in the first semester of the academic year of 2013/2014. The research variables consisted of independent variable (the use of Powerpoint media) and dependent variables (students' learning outcomes and interest). The research sample was IV A students of Muhammadiyah Sagan elementary school, in the academic year of 2013-2014. The data were collected through testing and non-testing. The data collecting instruments were a multiple choice test of learning outcomes and a questionnaire of learning interest. The reseach data were taken from the results of testing and non-testing, by comparing the mean of pre and post learning. The research result shows that the use of Powerpoint media has effect on students' outcomes and interest.
\end{abstract}

Keywords: Powerpoint media, learning interest, learning outcomes. 


\section{Pendahuluan}

Perkembangan teknologi sekarang ini telah banyak menunjukkan kemajuan yang luar biasa. Banyak hal dari sektor kehidupan yang telah menggunakan teknologi. Kehadirannya telah memberikan dampak yang cukup besar terhadap kehidupan umat manusia dalam berbagai aspek dan dimensi. Kemajuan teknologi dan informasi turut pula menjadi pemicu perubahan dalam sistem pembelajaran, yakni upaya untuk melepaskan dunia pendidikan dari kungkungan model pembelajaran konvensional.

Strategi pembelajaran yang dapat membuat siswa aktif adalah strategi pembelajaran yang berorientasi pada siswa (student centered learning) bukan pada guru (teacher centered learning). Pembelajaran yang menyenangkan dapat terjadi apabila hubungan interpersonal antara guru dan siswa berlangsung baik. Banyak cara yang dapat dilakukan untuk membuat suasana pem-belajaran berlangsung menyenangkan. Pembelajaran yang menyenangkan dapat dicapai karena siswa didik aktif selama proses pembelajaran. Selain itu, minat belajar juga memiliki andil yang tinggi terhadap suasana senang belajar. Supaya minat belajar tetap tinggi, guru perlu memberikan umpan balik terhadap hasil belajar yang telah dicapai atau tugas yang telah diselesaikan oleh siswa.

Selain pemilihan strategi dan metode pembelajaran, untuk menciptakan pembelajaran yang berorientasi pada siswa, membuat siswa aktif dan menciptakan suasana pembelajaran yang menyenangkan dapat didukung dengan penggunaan media pembelajaran yang sesuai. Media pembelajaran adalah segala sesuatu yang menyangkut software dan hardware yang dapat digunakan untuk meyampaikan isi materi ajar dari sumber belajar ke pembelajar (individu atau kelompok), yang dapat merangsang pikiran, perasaan, perhatian dan minat pembelajar sedemikian rupa sehingga proses belajar (di dalam/di luar kelas) menjadi lebih efektif.
Koesnandar, (2003, p. 3) menyebutkan tentang "cara menjelaskan materi pelajaran dengan menggunakan media adalah dengan membawa gambar, foto, film, video tentang obyek tersebut". Cara ini akan sangat membantu guru dalam memberikan penjelasan. Selain menghemat kata-kata, waktu dan penjelasan pun akan lebih mudah dipahami oleh murid, menarik, membangkitkan minat belajar, menghilangkan kesalahan pemahaman, serta informasi yang disampaikan lebih konsisten.

Dengan cara tersebut di atas maka penggunaan media sangat diperlukan dalam proses pembelajaran, terutama untuk materi-materi yang sangat sulit dipahami apabila dijelaskan dengan cara yang lain. Untuk itu maka sekaranglah saatnya pembelajaran IPA di SD harus dibuat menyenangkan agar siswa menjadi lebih berminat untuk belajar IPA.

Menurut Baugh (Achsin, 1986) bahwa pemerolehan hasil belajar melalui indera pandang (mata) dan indera pendengaran (telinga) sangat menonjol perbedaannya. Kurang lebih $90 \%$ hasil belajar seseorang diperoleh melalui indera pandang, dan hanya sekitar 5\% dari indera pendengaran serta $5 \%$ lagi dari indera lainnya.

Dale (Arsyad, 2011, p.10) memperkirakan bahwa pemerolehan hasil belajar melalui indera pandang sekitar $75 \%$, melalui indera pendengaran sekitar 13\% dan indera lainnya $12 \%$. Kemudian penelitian yang pernah dilakukan Arief (Wahyudin, 2010, p.58), menunjukkan bahwa pengetahuan seseorang diperoleh dari pengalaman pendengaran $11 \%$, pengalaman penglihatan $83 \%$. Sedangkan kemampuan daya ingat yaitu berupa pengalaman apa yang dilihat $50 \%$.

Berdasarkan pengalaman tersebut jelas terlihat bahwa posisi media pembelajaran memiliki pengaruh yang cukup besar dalam proses pembelajaran. Hal ini karena media pembelajaran memiliki kemampuan merangsang minat belajar siswa, menghadirkan objek secara langsung atau replikanya, membuat hal yang abstrak 
menjadi konkrit, memberikan kesamaan persepsi, mengatasi hambatan waktu, tempat, jumlah, jarak serta penyajian ulang informasi secara konsisten dan memberikan suasana belajar yang santai, dan menarik, sehinggga dapat mencapai tujuan pembelajaran (Sanaky, 2013, p.7). Kegiatan belajar dengan menggunakan media Powerpoint seperti ini sesuai dengan karakteristik anak usia SD yang secara umum masih berada pada tahap operasional konkrit.

Pembelajaran IPA siswa SD hendaknya menggunakan alat bantu untuk menjelaskan materi pelajaran, sehingga siswa menjadi lebih memahami serta berminat untuk belajar IPA. Selain itu, melibatkan benda-benda pada lingkungan sekitar sangat membantu siswa dalam memahami objek pembelajaran dengan cara menghadirkan obyek tersebut ke ruangan belajar siswa, dengan demikian maka pengunaan media sangat membantu guru dalam mengajarkan konsep-konsep IPA di SD.

Faktor penting dalam media adalah adanya simulasi. Simulasi berpotensi membantu siswa kelompok eksperimen dalam melihat fakta/fenomena kongkret dalam pelajaran IPA maupun membantu memahami konsep abstrak dalam pelajaran IPA (Alessi \& Trollip, 2001, p.215).

Faktor yang dapat membangkitkan dan merangsang minat adalah faktor bahan pelajaran yang akan diajarkan kepada siswa. Bahan pelajaran yang menarik minat siswa, akan sering dipelajari oleh siswa yang bersangkutan. Sebaliknya bahan pelajaran yang tidak menarik minat siswa tentu akan dikesampingkan oleh siswa, sebagaimana telah ditulis oleh Slameto (2010, p.57) bahwa "minat mempunyai pengaruh yang sangat besar terhadap belajar, karena bila bahan pelajaran yang dipelajari tidak sesuai dengan minat siswa, maka siswa tidak akan belajar dengan sebaik-baiknya, karena tidak ada daya tarik baginya".

Dari penjelasan di atas dapat disimpulkan bahwa belajar adalah suatu proses yang kompleks dengan banyak faktor yang mempengaruhinya. Untuk memperoleh ha- sil belajar yang baik, siswa harus mempunyai perhatian dan minat terhadap materi pelajaran, selain itu kemampuan guru dalam menggunakan media pembelajaran yang sesuai dengan materi pelajaran, karena media pembelajaran yang sesuai dapat mempengaruhi hasil belajar.

Aspek Powerpoint dalam penelitian ini yang sangat menonjol adalah aspek visualnya. Livi dan Lentz 1982 (Sanaky, 2013, p.7) mengemukakan empat fungsi media pembelajaran yang khusunya pada media visual, yaitu: (1) fungsi atensi, media visual merupakan inti, menarik, dan mengarahkan perhatian pembelajar untuk berkonsentrasi kepada isi pelajaran yang berkaitan dengan makna visual yang ditampilkan atau menyertai teks materi pelajaran; (2) fungsi afektif, media visual dapat terlihat dari tingkat kenikmatan pembelajar ketika belajar membaca teks bergambar. Gambar atau lambang visual akan dapat mengugah emosi dan sikap pembelajar; (3) Fungsi kognitif, media visual mengungkapkan bahwa lambang visual memperlancar pencapaian tujuan untuk memahami dan mendengar informasi atau pesan yang terkandung dalam gambar; dan (4) fungsi kompensatoris, media visual memberikan konteks untuk memahami teks membantu pembelajar yang lemah dalam membaca untuk mengorganisasikan informasi dalam teks dan mengingatkannya kembali.

SD Muhammadiyah Sagan merupakan sekolah yang tergolong cukup berprestasi dan memiliki sarana dan prasarana yang mencukupi untuk mendukung proses pembelajaran dengan menggunakan media Powerpoint. Pada ruangan kelas IV, $\mathrm{V}$, dan VI sudah memiliki LCD proyektor dan beberapa materi pelajaran sudah menggunakan Powerpoint sebagai media pembelajaran di SD Muhammadiyah Sagan. Akan tetapi hanya beberapa materi pelajaran IPA di kelas IV yang ada media tayangnya (media Powerpoint), salah satu penyebabnya adalah terbatasnya kemampuan guru untuk membuat media pembelajaran dengan Powerpoint. 
Hasil pengamatan peneliti di kelas IV SD Muhammadiyah Sagan menunjukkan bahwa siswa kurang berminat mengikuti pembelajar IPA tanpa menggunakan media pembelajaran yang mengakibatkan siswa cendrung tidak memperhatikan pada saat guru menjelaskan materi. Kurangnya minat belajar siswa pada pembelajaran IPA telihat dari nilai hasil belajar pra penelitian yang dilakukan di kelas IV SD Muhammadiyah Sagan dengan rata-rata 60,77 dari 30 soal pertanyaan tentang pembelajaran IPA.

Rumusan masalah dalam penelitian ini adalah: (1) apakah terdapat pengaruh media Powerpoint terhadap minat belajar siswa pada pembelajaran IPA di kelas IV SD Muhammadiyah Sagan? (2) apakah terdapat pengaruh media Powerpoint terhadap hasil belajar siswa pada pembelajaran IPA di kelas IV SD Muhammadiyah Sagan?

Tujuan penelitian ini adalah: (1) mengetahui pengaruh penggunaan media Powerpoint terhadap minat belajar IPA siswa kelas IV SD Muhammadiyah Sagan; (2) mengetahui pengaruh penggunaan media Powerpoint terhadap hasil belajar IPA siswa kelas IV SD Muhammadiyah Sagan.

Media pembelajaran merupakan bagain dari komponen pembelajaran (urutan instruksional, metode, media dan waktu) yang digunakan secara bersama-sama guna efektifitas pembelajaran. Media pembelajaran yang dieksperimenkan dalam penelitian ini yaitu media pembelajaran berbentuk Powerpoint. Media Powerpoint adalah sebuah media pembelajaran yang digunakan untuk menyampaikan materi IPA kepada siswa kelompok eksperimen.

Minat merupakan suatu kecenderungan dan kegairahan yang tinggi atau ketertarikan yang besar terhadap sesuatu. Minat belajar siswa yang dimaksud dalam penelitian ini adalah minat terhadap materi IPA maupun terhadap proses pembelajarannya. Minat belajar siswa dinyatakan dalam hasil angket siswa.

Minat berperan sangat penting dalam kehidupan siswa dan mempunyai dampak yang besar terhadap sikap dan perilaku. Siswa yang berminat terhadap kegiatan belajar akan berusaha lebih keras dibandingkan siswa yang kurang berminat. Menurut Collette \& Chiapetta (1994: p.74) mengatakan bahwa: "Interest, like attitude, is a critical in science education. This affective construct reflects one's willingness to engage in an activity, rather than one's evaluation of it. Interest is defined as curiosity or fascination for an idea or event that engages attention."

Dari uraian di atas dapat diartikan bahwa minat, sama seperti sikap adalah sebuah konsep sangat penting dalam pendidikan sains. Sikap ini membangun sebuah refleksi kesiapan untuk menggunakannya dalam suatu aktivitas. Minat didefinisikan sebagai rasa ingin tahu atau ketertarikan untuk memberi perhatian serta menggunakan sebuah peristiwa atau ide.

Hasil belajar biasanya dinyatakan dengan skor yang diperoleh dari suatu tes hasil belajar yang diadakan setelah mengikuti suatu program pembelajaran. Hasil belajar yang diharapkan dalam pembelajaran IPA di SD adalah siswa memperoleh pemahaman yang lebih mendalam tentang IPA. Peningkatan minat dan hasil belajar yang diinginkan dalam penelitian ini dipengaruhi oleh cara penyajian materi pembelajaran dengan menggunakan Powerpoint.

Sudjana, (2012, p.22) menyatakan bahwa "hasil belajar merupakan kemampuan-kemampuan yang dimiliki setelah seseorang memiliki pengalaman belajarnya." Menurut Jihad \& Haris, (2008, p.15) "hasil belajar adalah perubahan tingkah laku siswa secara nyata setelah dilakukan proses belajar mengajar yang sesuai dengan tujuan pembelajaran.

Menurut Phillips (1994) "Learning outcomes are statements that specify what learners will know or be able to do as a result of a learning activity. Outcomes are usually expressed as knowledge, skills, or attitudes". Artinya: Hasil pembelajaran adalah pernyataan yang menentukan apa yang siswa tahu atau mampu lakukan sebagai hasil dari kegiatan belajar. Hasil belajar biasanya dinyatakan sebagai pengetahuan, keterampilan, atau sikap. 
Hasil belajar yang dimaksud dalam penelitian ini merupakan perubahan tingkah laku individu yang meliputi pengetahuan, keterampilan dan sikap yang merupakan hasil dari aktifitas yang ditunjukkan dengan angka.Hasil belajar dinyatakan dalam bentuk tes dengan skor nilai 0-100.

\section{Metode Penelitian}

Jenis penelitian ini adalah penelitian kuantitatif dengan desain penelitian Quasi-experiment design: One-GroupPre-testPost-test Design dengan satu macam perlakuan. Digunakan desain penelitian quasi eksperiment ini karena dalam bidang pendidikan seringkali sulit melakukan eksperimen secara murni. Dalam hal ini, karena subjek (siswa) adalah bukan sesuatu yang dapat dipindah, diperlakukan, dan diatur secara ketat sebagaimana pada penelitian bidang eksak.

Secara umum penelitian ini bertujuan untuk mengetahui pengaruh media Powerpoint terhadap minat dan hasil belajar IPA antara sebelum pembelajaran (pre-test) dengan sesudah pembelajaran (post-test) pada mata pelajaran IPA di kleas IV SD Muhammadiyah Sagan.

Rancangan penelitian menggunakan Pre-test-Post-test Design. Pre-test-Pos-test Design adalah suatu desain penelitian yang membandingkan pre-test dengan post-test pada satu kelompok uji, yaitu kelompok kelompok eksperimen. Hasil pre-test akan dibandingkan dengan post-test, kemudian baru diambil kesimpulan melalui deskripsi data minat belajar dan hasil belajar IPA

Penelitian ini dilaksanakan di SD Muhammadiyah Sagan. Alasan pemilihan sekolah tersebut sebagai tempat penelitian adalah karena sekolah tersebut sudah memiliki sarana dan prasarana untuk menggunakan media Powerpoint.

Berdasarkan survei yang dilaksanakan pada bulan September 2013 diketahui permasalahan secara objektif tentang proses pembelajaran IPA di kelas IV SD Muhammadiyah Sagan yaitu sudah pernah menggunakan media Powerpoint dalam pembelajaran IPA tapi kurang intensif, karena kurangnya materi yang dirancang dengan media Powerpoint. Penelitian telah dilaksanakan pada bulan Nopember-Desember 2013. Pemilihan waktu tersebut sesuai dengan pelaksanaan pembelajaran IPA di SD Muhammadiyah Sagan.

Subjek penelitian ini adalah semua siswa kelas IV SD Muhammadiyah Sagan Tahun Ajaran 2013-2014 yang terdiri dari dua kelas IV A. Penentuan kelompok eksperimen melalui pengundian dan diperoleh kelas IV A sebagai kelompok eksperimen dengan jumlah 44 orang siswa dan kelas VI B sebagai kelompok uji coba instrumen penelitian dengan jumlah yang diambil sebanyak 30 orang siswa.

Pada pembelajaran IPA kelompok eksperimen diberi perlakuan dengan menggunakan media Powerpoint. Rancangan penelitian menggunakan Pre-test-Posttest Design. Pre-test-Pos-test Design adalah suatu desain penelitian yang membandingkan pre-test dengan post-test pada kelompok eksperimen. Hasil pre-test akan dibandingkan dengan post-test, kemudian baru diambil kesimpulan melalui deskripsi data minat belajar dan hasil belajar IPA.

Sebelum treatment diberikan pre-test atau tes awal berupa soal-soal yang berhubungan dengan materi IPA untuk melihat tingkat kondisi subyek yang berkenaan dengan variabel terikat. Setelah percobaan selesai, dilakukan post-test atau test akhir dengan soal-soal yang tidak jauh berbeda. Data skor hasil belajar pre-test dan post-test kemudian dibandingkan. Tujuan perbandingan ini adalah untuk mengetahui pengaruh dari penggunaan media Powerpoint.

Langkah-langkah perlakuan/treatment adalah: (a) materi pelajaran disampaikan dengan menggunakan media tayang berupa slide Powerpoint tentang benda, sifat dan kegunaannya dan siswa memperhatikan secara seksama; (b) pengorganisasian siswa untuk belajar: pada tahap ini siswa berkelompok dengan jumlah kelompok masing-masing 5-6 orang, selanjutnya masing-masing kelompok mengerjakan LKS; (c) perwakilan kelompok membaca- 
kan hasil kerjanya didepan kelas dan kelompok lain menanggapi atau memberikan pertanyaan; (d) diskusi kelas tentang materi pelajaran benda, sifat dan kegunaannya; (e) Guru bersama siswa menyimpulkan pelajaran yang telah dilaksanakan.

Data yang diperoleh terdiri atas data skor minat belajar dan skor hasil belajar IPA siswa kelompok eksperimen. Instrumen yang digunakan adalah angket minat belajar dan tes hasil belajar IPA. Teknik pengumpulan data yang digunakan dalam penelitian ini terdiri dari 2 macam, yaitu: (1) pemberian angket kepada siswa; (2) pemberian tes hasil belajar.

Pertama, angket digunakan untuk mengetahui bagaimana minat belajar siswa kelompok eksperimen pada mata pelajaran IPA sebelum diberikan perlakuan maupun sesudah diberikan perlakuan. Angket yang dibuat menggunakan skala Likert dengan 4 alternatif jawaban yaitu: sangat setuju, setuju, tidak setuju dan sangat tidak setuju dan skor masing-masing 4, 3, 2, dan 1 .

Kedua, Tes hasil belajar yang diberikan berupa soal-soal dengan 4 alternatif pilihan jawaban (pilihan ganda).Tes hasil belajar yang diberikan adalah berupa pre-test dan post-test.Tes ini diberikan untuk mengukur aspek kognitif siswa dalam menguasai dan memahami materi IPA.

Analisis data dalam penelitian ini menggunakan analisis data statistik deskriptif. Statistik deskriftif untuk mengetahui tingkat keefektifan pembelajaran IPA. Teknik analisis deskriptif yang digunakan yaitu dengan mengungkap apa yang terjadi. Dengan ini peneliti berusaha mendeskripsikan kejadian-kejadian, aktifitas, dan kondisi pada saat implementasi program. Selanjutnya data yang diperoleh hasilnya dikumpulkan, dideskripsikan untuk kemudian disimpulkan.

Pada data angket didapatkan mean $(\bar{M})$, median (Me), modus (Mo), standar deviasi (SD), rentang nilai maksimum dan nilai minimum pada setiap variabel. Menurut Arifin (2009, p.236), penafsiran hasil pengukuran berdasarkan penilaian acuan patokan (PAP), kategori hasil pengukuran dengan menggunakan skala 5 kriteria

Data dianalisis untuk mengetahui pengaruh media Powerpoint terhadap minat belajar siswa dan hasil belajar siswa berdasarkan pre-test dan post-test pada kelompok eksperimen.

\section{Hasil Penelitian dan Pembahasan}

\section{Deskripsi Data Minat belajar}

Hasil angket yang diberikan sebelum pembelajaran disajikan pada Tabel 1, menunjukkan bahwa nilai mean minat belajar sebelum pembelajaran adalah 99,84 dengan standar deviasi 8,70, nilai terendah 78 dengan frekuensi 1 siswa dan nilai tertinggi 120 dengan frekuensi 1 siswa. Selanjutnya hasil mean minat belajar sesudah pembelajaran adalah 113,61 dengan standar deviasi 4,63 nilai terendah 102 dengan frekuensi 1 siswa dan nilai tertinggi adalah 120 dengan frekuensi 5 siswa.

Tabel 1. Deskripsi Data Skor Minat Belajar

\begin{tabular}{lcc}
\hline \multirow{2}{*}{ Statistik } & \multicolumn{2}{c}{ Minat Belajar } \\
\cline { 2 - 3 } N $\quad$ Valid & Sebelum & Sesudah \\
\hline \multicolumn{1}{c}{$\quad$ Missing } & 44 & 44 \\
Mean & 0 & 0 \\
Median & 99,84 & 113,61 \\
Mode & 97,50 & 115 \\
Std. Deviation & 97 & 116 \\
Minimum & 8,70 & 4,63 \\
Maksimum & 78 & 102 \\
Sum & 120 & 120 \\
\hline
\end{tabular}

Dapat dijelaskan dalam skala lima dengan Penilaian Acuan Patokan (PAP) data tersebut membentuk distribusi frekuensi seperti disajikan pada Tabel 2.

Dari Tabel 2 dapat dilihat data minat belajar dari kelompok eksperimen sebelum pembelajaran IPA, 8 siswa atau $18,18 \%$ diantaranya masuk dalam kategori minat belajar yang sangat baik, 27 siswa atau $61,36 \%$ masuk dalam kategori yang baik, 8 siswa atau 18,18\% masuk dalam kategori cukup, dan 1 siswa atau 2,27\% masuk dalam kategori kurang. 
Tabel 2. Distribusi Frekuensi Minat Belajar

\begin{tabular}{ccccc}
\hline \multirow{2}{*}{ Kategori } & \multicolumn{2}{c}{ Sebelum } & \multicolumn{2}{c}{ Sesudah } \\
\cline { 2 - 5 } & Jml & $\%$ & Jml & $\%$ \\
\hline A & 8 & 18,18 & 39 & 88,68 \\
B & 27 & 61,36 & 5 & 11,36 \\
C & 8 & 18,18 & 0 & 0 \\
D & 1 & 2,27 & 0 & 0 \\
E & 0 & 0 & 0 & 0 \\
Total & 44 & 100 & 44 & 100 \\
\hline
\end{tabular}

Selanjutnya untuk minat belajar sesudah pembelajaran, 39 siswa atau $88,68 \%$ masuk ke dalam kategori minat belajar yang sangat baik, sedangkan sisanya 5 siswa atau 11,36\% masuk ke dalam kategori yang baik. Apabila digambarkan dalam histogram akan nampak seperti pada Gambar 1.

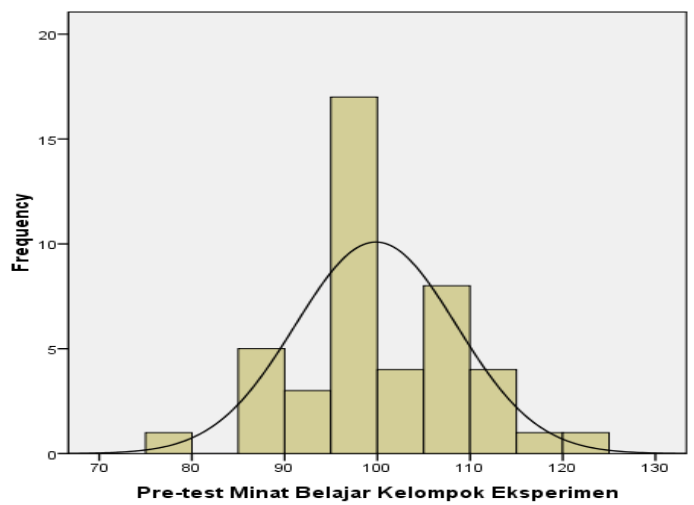

Gambar 1. Distribusi Frekuensi Minat Belajar (sebelum Pembelajaran)

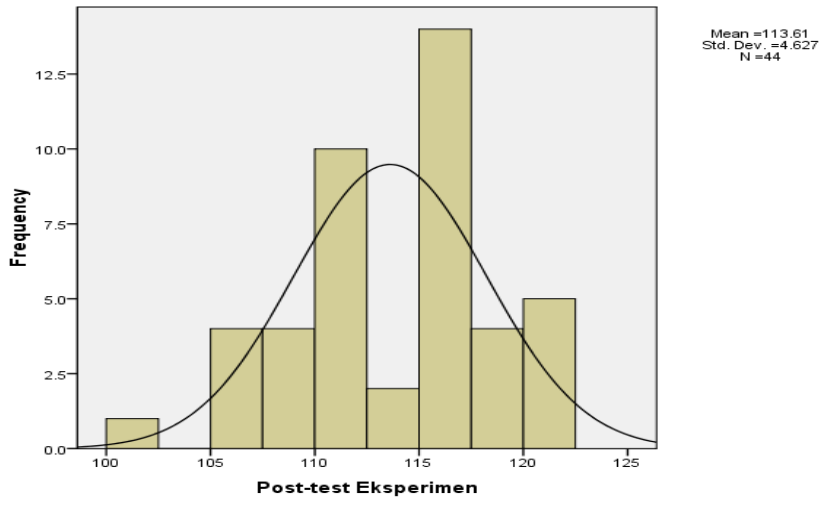

Gambar 2. Distribusi Frekuensi Minat Belajar (sesudah Pembelajaran)

Dari data minat belajar ini terdapat peningatan minat belajar sebelum dan sesudah pembelajaran IPA sebesar 13,77 atau $11,47 \%$. Selisih hasil angket minat belajar sebelum dan sesudah pembelajaran berbeda secara signifikan, artinya media Powerpoint berpengaruh positif terhadap minat belajar siswa pada pembelajaran IPA di kelas IV SD Muhammadiyah Sagan.

\section{Deskripsi Data Hasil Belajar (Pre-test dan} Post-test)

Hasil pre-test pada Tabel 3 menunjukkan bahwa nilai mean 71,82 dengan standar deviasi 9,66 nilai terendah 50 dengan frekuensi 2 siswa dan nilai tertinggi 96,67 dengan frekuensi 1 siswa. Selanjutnya hasil post-test menunjukkan bahwa nilai mean hasil belajar siswa pada mata pelajaran IPA adalah 85,83 dengan standar deviasi 7,65 nilai terendah 63,33 dengan frekuensi 1 siswa dan nilai tertinggi 100 dengan frekuensi 1 siswa.

Tabel 3. Deskripsi Data Skor Hasil Belajar

\begin{tabular}{lcc}
\hline \multirow{2}{*}{ Statistik } & \multicolumn{2}{c}{ Hasil Belajar } \\
\cline { 2 - 3 } N $\quad$ Palid & 44 -test & Post-test \\
\hline Missing & 0 & 44 \\
Mean & 71.82 & 85,83 \\
Median & 70 & 86,67 \\
Mode & 70 & 86,67 \\
Std. Deviation & 9,66 & 7,65 \\
Minimum & 50 & 63,33 \\
Maksimum & 96,67 & 100 \\
Sum & 3160 & 3777 \\
\hline
\end{tabular}

Dapat dijelaskan dalam skala lima dengan Penilaian Acuan Patokan (PAP) data tersebut membentuk distribusi frekuensi seperti disajikan pada Tabel 4.

Dari Tabel 4 dapat dilihat frekuensi untuk pre-test, 2 siswa atau 4,55\% diantaranya masuk dalam kategori hasil belajar yang sangat baik, 8 siswa atau 18,18\% masuk dalam kategori yang baik, 20 siswa atau $45,45 \%$ masuk dalam kategori yang cukup, 11 siswa atau 27,27\% masuk dalam kategori kurang, dan 2 siswa atau 4,55\% masuk dalam kategori sangat kurang. 
Tabel 4. Distribusi Frekuensi Hasil Belajar

\begin{tabular}{ccccc}
\hline \multirow{2}{*}{ Kategori } & \multicolumn{2}{c}{ Pre-test } & \multicolumn{2}{c}{ Post-test } \\
\cline { 2 - 5 } & Jumlah & $\%$ & Jumlah & $\%$ \\
\hline A & 2 & 4,55 & 17 & 38,64 \\
B & 8 & 18,18 & 19 & 43,18 \\
C & 20 & 45,45 & 7 & 15,91 \\
D & 11 & 27,27 & 1 & 2,27 \\
E & 2 & 4,55 & 0 & 0 \\
Total & 44 & 100 & 44 & 100 \\
\hline
\end{tabular}

Selanjutnya frekuensi untuk posttest, 17 siswa atau 38,64\% masuk dalam kategori hasil belajar yang sangat baik, 19 siswa atau 43,18\% masuk dalam kategori baik, 7 siswa atau 15,91\% masuk dalam kategori cukup, sedangkan 1 siswa atau 2,27\% masih masuk dalam kategori yang kurang. Apabila digambarkan dalam histogram akan nampak sebagai berikut:

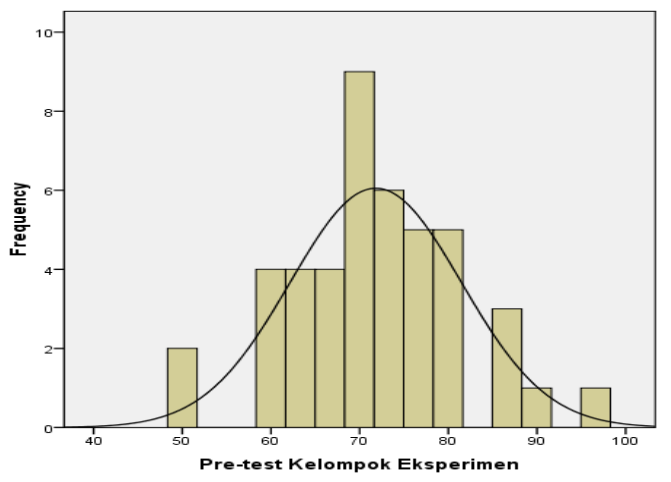

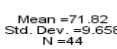

Gambar 3. Distribusi Frekuensi Hasil Belajar (Pre-test)
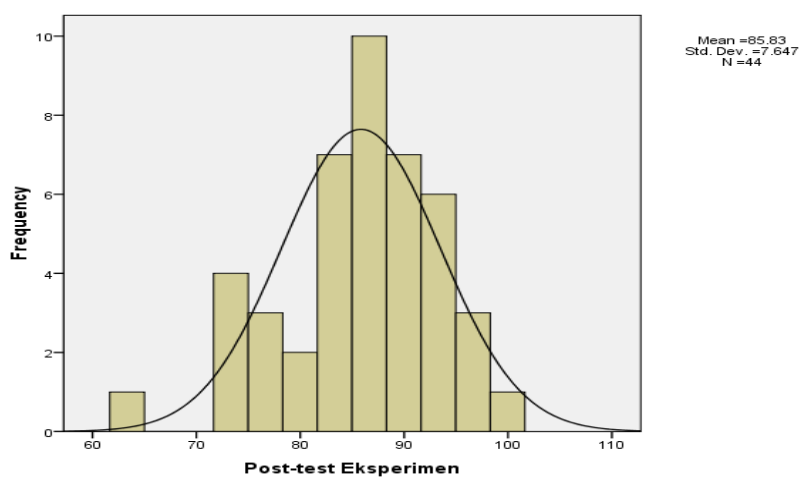

Gambar 4. Distribusi Frekuensi Hasil Belajar (Post-test)

Berdasarkan data hasil belajar ini terdapat peningatan hasil belajar dari pretest dan post-test sebesar 14,01 atau $14,01 \%$.
Selisih hasil pre-test dan postest berbeda secara signifikan, artinya media Powerpoint berpengaruh positif terhadap hasil belajar siswa pada pembelajaran IPA di kelas IV SD Muhammadiyah Sagan.

Pada hipotesis data minat belajar untuk mengetahui perbedaan hasil sebelum dan sesudah pembelajaran dengan menggunakan media Powerpoint pada pembelajaran IPA, menghasilkan skor rata-rata sebelum pembelajaran 99,84 dan sesudah pembelajaran 113,61. Di dalam uji rata-rata dengan program SPSS versi 16.00 for Windows menu uji $t$ berpasangan, menghasilkan angka sig. 0,000 untuk taraf signifikan a $(0,05)$. Perbedaan rata-rata tersebut sebesar 13,77 atau sebesar $11,48 \%$. Hasil ini menunjukkan bahwa antara sebelum dan sesudah pembelajaran dengan menggunakan media Powerpoint terdapat perbedaan. Artinya adalah terdapat perbedaan minat belajar antara sebelum dan sesudah pembelajaran yang menggunakan media Powerpoint.

Hasil Uji Hipotesis

\section{Pengujian Hipotesis Pertama}

Hipotesis pertama berbunyi: Terdapat perbedaan minat belajar siswa sebelum dan sesudah eksperimenpada pembelajaran IPA yang mengunakan media Powerpoint.

\section{Pengujian Hipotesis Kedua}

Hipotesis kedua berbunyi: Terdapat perbedaan hasil belajar siswa pre-test dan post-test pada pembelajaran IPAyang mengunakan media Powerpoint.

Selisih skor minat belajar dicari dengan membandingkan rerata antara sebelum perlakuan 99,84 dan sesudah perlakuan 113,61 dengan hasil 13,773. Jadi terdapat perbedaan minat belajar siswa sebelum dan sesudah pada kelompok eksperimen yang menggunakan Powerpoint.

Selisih skor hasil belajar dicari dengan membandingkan rerata antara pretest 71,82 dan post-test 85,83 dengan hasil 14,015 . Jadi terdapat perbedaan hasil 
belajar siswa pre-test dengan post-test pada kelompok eksperimen yang menggunakan media Powerpoint.

Pembahasan

Pengaruh Penggunaan Media Powerpoint terhadap Minat Belajar

Pada hipotesis data minat belajar untuk mengetahui perbedaan skor sebelum dan sesudah pembelajaran dengan menggunakan media Powerpoint pada pembelajaran IPA, menghasilkan skor rata-rata sebelum pembelajaran 99,84 dan sesudah pembelajaran 113,61. Hasil ini menunjukkan bahwa antara sebelum dan sesudah pembelajaran dengan menggunakan media Powerpoint terdapat perbedaan. Artinya adalah terdapat perbedaan minat belajar antara sebelum dan sesudah pembelajaran pada kelompok eksperimen yang menggunakan media Powerpoint.

Miarso (2009, p.459), menyebutkan bahwa "Media membangkitkan keinginan dan minat baru. Dengan menggunakan media pendidikan, horizon pengalaman anak semakin luas, persepsi semakin tajam, konsep-konsep dengan sendirinya semakin lengkap. Akibatnya keinginan dan minat untuk belajar selalu muncul".

Hal yang terjadi pada dua sampel penelitian ini (sebelum dan sesudah pembelajaran) secara prinsip adalah mengenai perbedaan dua hal, yaitu proses pembelajaran dan media. Mengenai proses pembelajaran, penggunaan media Powerpoint ini membawa konsekwensi pada jalannya pembelajaran yang menarik minat belajar siswa. Akibat dari kedua keadaan ini adanya pengaruh media Powerpoint terhadap minat belajar siswa dalam pembelajaran IPA tersebut. Seperti tertuang pada hasil penelitian untuk hipotesis yang pertama (mengenai minat) ini, jelas terlihat perbedaan yang cukup signifikan antara minat belajar siswa pada sebelum dan sesudah pembelajaran.

Pada saat perlakuan/treatment siswa berkesempatan untuk melihat demonstrasi yang ada pada Powerpoint yang me- miliki unsur gambar, suara dan video pembelajaran sehingga audio visual anak aktif, sedangkan sebelumnya siswa tidak menggunakan media Powerpoint.

Faktor-faktor penumbuh minat yaitu motivasi, perhatian, rasa senang, dan cita-cita/harapan, pada saat perlakuan/ treatment terfasilitasi dengan baik. Pengetahuan tersedia secara gamblang pada media Powerpoint, sehingga siswa dapat melakukan pengamatan. Persepsi siswa terpupuk dengan baik akibat pengamatan yang baik pula. Hal ini pada akhirnya menumbuhkan sikap yang baik terhadap pembelajaran dan materi, sehingga minat belajar siswa sesudah pembelajaran jauh lebih baik dibanding sebelumnya.

Mengenai peranan media pembelajaran. Media yang digunakan pada saat perlakuan/treatment adalah media Powerpoint. Media ini berpotensi membuat siswa bergairah untuk belajar dan membuat anak tetap fokus pada pelajaran yang diajarkan sampai pelajaran berakhir. Adanya gambar-gambar yang memperjelas materi dan video untuk contoh kegiatan juga menambah menarik media ini.

Berdasarkan teori yang mendasari faktor-faktor yang mempengaruhi minat belajar, dan dengan melihat kenyataan yang terjadi di lapangan (pada pelaksanaan penelitian eksperimen) didapatkan hasil yang memperkuat teori tersebut. Didapatkan hasil bahwa memang benar (terbukti secara signifikan) pembelajaran dengan menggunakan media Powerpoint dapat berpengaruh positif terhadap minat belajar siswa.

\section{Pengaruh Penggunaan Media Powerpoint terhadap Hasil Belajar Siswa}

Pada hipotesis data hasil belajar, yaitu untuk mengetahui perbedaan hasil pre-test dan post-test kelompok eksperimen yang menggunakan media Powerpoint pada pembelajaran IPA, menghasilkan skor ratarata 71,82 untuk pre-test dan 85,83 untuk post-test. Hasil ini menunjukkan bahwa antara pre-test dan post-test yang menggunakan media Powerpoint terdapat per- 
bedaan. Artinya adalah terdapat perbedaan hasil belajar antara pre-test dan post-test kelompok eksperimen yang menggunakan media Powerpoint.

Salah satu faktor yang memengaruhi hasil belajar yaitu faktor eksternal yang di dalamnya terdapat faktor kurikulum dan fasilitas belajar. Proses pembelajaran dan media yang digunakan merupakan bentuk kongkrit dari faktor yang mempengaruhi hasil belajar, dan yang terjadi pada dua sampel penelitian ini (pretest dan post-test) secara prinsip adalah mengenai perbedaan dua hal di atas, yaitu proses pembelajaran dan media. Mengenai proses pembelajaran. Perlakuan Universitas Negeri Yogyakarta / treatment ke siswa mengakibatkan hasil belajar yang cukup berbeda dengan sebelumnya. Pada saat perlakuan/treatment siswa diberikan media pembelajaran Powerpoint dimana siswa disuguhkan gambar-gambar dan video yang relevan dengan pembelajaran IPA. Sedangkan pembelajaran IPA sebelumnya tidak menggunakan media Powerpoint.

Pembelajaran IPA yang menggunakan media Powerpoint yang ada unsurunsur multimedia telah membawa akibat yang cukup berbeda terhadap siswa. Seperti sudah disebutkan di atas, pada saat perlakuan/treatment yang menggunakan media Powerpoint, siswa mendapatkan berbagai kemudahan yang tidak didapatkan sebelumnya seperti video pembelajaran dan gambar-gambar relevan yang berhubungan dengan materi pelajaran.

Mengenai peranan media pembelajaran, saat perlakuan/treatment menggunakan media berupa slide-slide Powerpoint IPA, perbedaan jelas terlihat dalam basis orientasi media, yaitu media Powerpoint berbasis persentasi dengan slide-slide Powerpoint dengan gambar-gambar dan video yang relevan dengan materi pelajaran. Hal ini mengakibatkan prilaku siswa dalam mengikuti jalannya pembelajaran yang berbeda pula. Inti perbedaannya adalah pada keberagaman media dalam mempelajari materi. Perbedaan yang sangat mencolok ini berpotensi mempengaruhi proses pe- mahaman materi. Pada kelompok eksperimen, siswa dapat mengamati gambargambar dan video pembelajaran.

Faktor penting dalam media adalah adanya simulasi. Simulasi berpotensi membantu siswa kelompok eksperimen dalam melihat fakta/fenomena kongkret dalam pelajaran IPA maupun membantu memahami konsep abstrak dalam pelajaran IPA (Alessi \& Trollip, 2001, p.215). Ditambah dengan adanya fasilitas mencoba berulangulang simulasi mendukung proses pemahaman pengetahuan siswa.

Dengan berdasarkan teori yang mendasari faktor-faktor yang mem-pengaruhi hasil belajar, dan dengan melihat kenyataan yang terjadi di lapangan (pada pelaksanaan penelitian eksperimen) didapatakan hasil yang memperkuat teori tersebut. Didapatkan hasil, bahwa memang benar (terbukti secara signifikan) pembelajaran dengan menggunakan media Powerpoint dapat berpengaruh terhadap hasil belajar IPA siswa.

\section{Simpulan dan Saran}

Simpulan

Terdapat pengaruh media Powerpoint terhadap minat belajar IPA siswa kelompok eksperimen pada pembelajaran yang menggunakan media Powerpoint. Minat belajar IPA siswa kelas IV SD Muhammadiyah Sagan meningkat 13,77 atau $11,48 \%$, yaitu dari hasil selisih rerataan sebelum pembelajaran 99,84 dengan hasil rerataan sesudah pembelajaran 113,61 .

Terdapat pengaruh media Powerpoint terhadap hasil belajar IPA siswa kelompok eksperimen pada pembelajaran yang menggunakan media Powerpoint. Hasil belajar IPA siswa kelas IV SD Muhammadiyah Sagan meningkat 14,01 atau $14,01 \%$, yaitu dari hasil selisih rerataan pretest 71,82 dengan hasil rerataan post-test 85,83 .

Saran

Kepada guru mata pelajaran IPA disarankan untuk meningkatkan penggu- 
naan media (salah satunya media Powerpoint) dalam pembelajaran IPA demi peningkatan minat dan hasil belajar siswa.

Minat siswa yang kuat perlu dipertahankan. Oleh karena itu memerlukan dukungan media pembelajaran yang lebih menarik minat siswa untuk terlibat dalam pembelajaran, maka diperlukan koordinasi dari guru, kepala sekolah, pengawas dan komite sekolah.

Perlu adanya kegiatan berkelanjutan agar terwujudnya pelaksanaan pembelajaran yang memerlukan media pembelajaran nonkonvensional.

Untuk kesempurnaan penelitian ini, disarankan kepada peneliti atau calon peneliti yang berminat untuk mengadakan penelitian lanjutan dengan membuat media Powerpoint yang mencakup materi pelajaran yang lebih luas lagi.

\section{Daftar Pustaka}

Allessi, M. \& Trolip, (2001). Computer Based Instructional Method and Development. Prentice Hall. New Jersey.

Arifin, Z. (2011). Evaluasi pembelajaran. Bandung: Remaja Rosdakarya.

Arsyad, A. (2011). Media pembelajaran. Jakarta: RajaGrafindo Persada.

Collette, A. T., \& Chiappetta, E. L. ((1994). Scince instruction in the middle and secondary schools (3 ${ }^{\text {rd }}$ ed.).New York: Macmillan.

Jihad, A., \& Haris, A. (2008). Evaluasi pembelajaran. Yogyakarta: Multi Pressindo.

Koesnandar, A. (2003). Guru dan Media Pembelajan.Diambil pada tanggal 21
Desember 2013, dari http:// ipislam.edu.my $/ \mathrm{kplir} / \mathrm{t}$ pdk/Jurnal\%20Teknodik\%20No_13 htm\#5.

Miarso, Y. (2009). Menyemai benih teknologi pendidikan. Jakarta: Kencana.

Phillips, L., (1994). The Continuing Education Guide: the CEU and Other Professional Development Criteria. Lowa: Hunt Publishing Co.Diambil pada tanggal 30 Januari 2014 dari http:/ / www.aallnet.org/Archived/Educat ion-and-Events/cpe/outcomes. html

Sanaky, H. AH. (2013) Media pembelajaran interaktif-inovatif. Yogyakarta: Kaukaba.

Slameto. (2010). Belajar \& faktor-faktor yang mempengaruhinya(Rev. ed.). Jakarta: Rineka Cipta.

Sudjana, N. (2012). Penilaian hasil proses belajar mengajar. Bandung: Remaja Rosdakarya.

Sugiyono. (2010). Metode penelitian pendidikan (Pendekatan kuntitatif, kualitatif, dan RED). Bandung: Alfabeta.

Wahyudin, S. (2010) Keefektifan pembelajaran berbantuan multimedia menggunakan metode inkuiri terbimbing untuk meningkatkan $\mathrm{m}$ inat dan pemahaman siswa. Jurnal Pendidikan Fisika Indonesia No. VI Januari 2010. Di ambil pada tanggal 21 Desember 2013 dari http://www.journal.unnesa.ac.id/ nju/index.php/JPFI?article/.../101 $\underline{6}$ 